\title{
Climate change and its impact on the properties of agricultural soils in the Argentinean Rolling Pampas
}

\author{
Raúl A. Díaz*, Graciela O. Magrin, María I. Travasso, Rafael O. Rodríguez \\ Instituto de Clima y Agua, Centro de Investigaciones en Recursos Naturales, Instituto Nacional de Tecnología Agropecuaria,
} 1712 Castelar, Buenos Aires, Argentina

\begin{abstract}
The agriculture of the Argentinean pampean region is undergoing a reconversion process as a result of a more intensive use of agrotechnologies. The ongoing changes are likely to overlap with the greenhouse warming-related climatic changes and atmospheric $\mathrm{CO}_{2}$ increase predicted for the next century. The goal of this study is to assess the potential impact of such changes on certain properties of soils of the Rolling Pampas, which support 10 to $15 \%$ of the national grain crop and oilseed production. Rotation of wheat/soybean-maize crops in 45 agricultural soils was simulated using the EPIC model (Erosion/Productivity Impact Calculator; US Dept of Agriculture), which was previously calibrated and validated for local conditions, for the 1996 to 2050 period under 2 scenarios: (1) no climate change, and (2) climate change conditions derived from regional climate parameters projected by the GISS general circulation model combined with a $\mathrm{CO}_{2}$ concentration of $550 \mathrm{ppm}$. The 1971 to 1995 period was simulated under neutral conditions with the purpose of defining soil conditions for 1996. It was found that in the event of a change in climate, physical proporties would change to a lesser degree than chemical properties. The soil bulk density would decrease by $8 \%$ with respect to the baseline scenario in soils under risk of erosion. In contrast, since it was assumed that the erosive storm pattern would remain unchanged, there would be no variations in the erosion rate. A general decrease in potential soil fertility of 6 to $10 \%$ for total organic $N$ and 7 to $20 \%$ for organic $C$ would take place after a $55 \mathrm{yr}$ period. The sustainability of certain soils of the Carcarana River basin, particularly the Villa Eloísa series, would be at a higher risk.
\end{abstract}

KEY WORDS: Simulation - EPIC · Soil fertility · Soil physical properties - Climate change

\section{INTRODUCTION}

The agriculture of the Argentinean pampean region is undergoing an intensification of grain production promoted by the government and private sectors. Analysts predict that this trend will continue well into the next century.

General circulation models (GCMs) predict an increase in temperature and precipitation in the pampean region (Burgos \& Molion 1991). Some studies further predict a global decrease in wheat yields as a consequence of climate change (Rodríguez \& Fernández 1993). Thus, impacts of the potential changes in cli-

\footnotetext{
•E-mail: rdiaz@inta.gov.ar
}

mate should be accounted for in the agrotechnological evolution of Argentinean agriculture.

The potential variations in the properties of agricultural soils are less well known. Díaz et al. (1994) have reported that under a climate change scenario the soil organic matter content and erosion rate would decrease with regard to current values in the Arrecifes River basin.

The goal of the present study was to assess potential modifications in the properties of the Rolling Pampas agricultural soils, which cover $45 \%$ of the area in this sub-region and support 10 to $15 \%$ of the nation's grain crop and oilseed production.

A simulation model following the method proposed by Easterling et al. (1992) was selected for evaluating the effects of a potential climate change on the vari- 
ables which affect water balance, nitrogen balance erosion rate and soil productivity.

\section{METHODS}

The climate change scenario was defined following a literature review process. Solar radiation, precipitation and monthly temperatures were modified in accordance with the selected scenario and then used as inputs for the EPIC (Erosion/Productivity Input Calculator) model. The values for radiation conversion efficiency and maximum stomatal conductance were also modified. The WXGEN weather generator included in the model was used to produce synthetic sequences of daily weather data, which interacted with the nutrient balance, erosion and crop growth submodels.

2.1. Climate change scenarios. The climate change scenario was based on regional information produced with the GISS general circulation model (NASA Goddard Institute for Space Studies; Hansen et al. 1988), coupled with a $\mathrm{CO}_{2}$ concentration of 550 ppm. Adjustment factors are presented in Table 1.

The weather stations considered were the following:

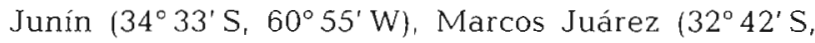
$\left.62^{\circ} 09^{\prime} \mathrm{W}\right)$, Oliveros $\left(32^{\circ} 33^{\prime} \mathrm{S}, 60^{\circ} 51^{\prime} \mathrm{W}\right)$, Pergamino $\left(33^{\circ} 56^{\prime} \mathrm{S}, 60^{\circ} 33^{\prime} \mathrm{W}\right)$, Rosario ( $\left.32^{\circ} 55^{\prime} \mathrm{S}, 60^{\circ} 47^{\prime} \mathrm{W}\right)$ and San Pedro $\left(33^{\circ} 41^{\prime} \mathrm{S}, 59^{\circ} 41^{\prime} \mathrm{W}\right)$. The Junin and Rosario stations belong to the Servicio Meteorológico Nacional (SMN), and the remainder to the Instituto Nacional de Tecnología Agropecuaria (INTA).

The advantage of using synthetic climate sequences for the analysis of climate change impacts on regional agriculture has been confirmed by previous studies (Favis-Mortlock et al. 1991).

2.2. The EPIC model. The EPIC model was developed in late 1985 to estimate the impacts of soil erosion on agricultural productivity in the USA. EPIC contains interrelated modules based on physical concepts which simulate erosion, crop growth, nutrient balance and other processes (Williams et al. 1984)

EPIC was adapted by Easterling et al. (1992) in order to simulate the responses of photosynthesis and evapotranspiration to an increase in $\mathrm{CO}_{2}$. For this pur-

Table 1 Adjustment factors for temperature, radiation and precipitation based on GISS model outputs for the pampean region

\begin{tabular}{|c|c|c|c|c|c|c|c|c|c|c|c|c|}
\hline Variable & Jan & Feb & Mar & Apr I & May & Jun & Jul & Aug & Sep & Oct & Nov & Dec \\
\hline Temperature & 5.7 & 5.1 & 6.1 & 5.5 & 5.0 & 4.1 & 4.3 & 5.2 & 3.6 & 3.3 & 4.3 & 5.4 \\
\hline Radiation $^{\mathrm{b}}$ & 1.0 & 1.0 & 1.0 & 1.0 & 1.1 & 1.1 & 1.1 & 1.0 & 1.1 & 1.0 & 1.1 & 1.0 \\
\hline Precipitation ${ }^{b}$ & 1.3 & 1.6 & 1.2 & 1.2 & 1.0 & 1.3 & 1.4 & 1.0 & 0.8 & 1.0 & 1.1 & 1.1 \\
\hline
\end{tabular}

pose, the original values for radiation conversion efficiency and maximum stomatal conductance were replaced by the values reported by Rosenzweig \& Parry (1994).

Model calibration and validation for the study area had been previously carried out with regard to tillage systems (Díaz 1993a), chemical degradation (Díaz \& Di Giacomo 1994) and crop productivity (Díaz 1993b).

The typical crop rotation system (involving one cropping season of wheat/soybean and of maize the next) was simulated for 45 agricultural soils of the Arrecifes and Carcaraña River basins of the Rolling Pampas for the 1971 to 1995 period. The soil terminology used includes an alphanumeric reference to the erosion risk: $\mathrm{H} 0=$ low; $\mathrm{H} 1$ = slight; $\mathrm{H} 2=$ moderate; $\mathrm{H} 3$ = severe .

In EPIC 100 different sequences of generated daily weather are possible. We tried 5 of them; since no significant differences were found among these scenarios, the one which best simulated the observed yield ranges for Pergamino County ('Partido de Pergamino') was selected. The final condition of the soil properties (1995) was used as input for the simulation of the 2 scenarios compared for the 1996 to 2050 period: (1) no climate change and $330 \mathrm{ppm}$ of $\mathrm{CO}_{2}$ - the baseline condition-and (2) climate change and $550 \mathrm{ppm}$ of $\mathrm{CO}_{2}$

The physical properties selected were: (1) soil depth, (2) field capacity, (3) wilting point, and (4) topsoil bulk density. The maximum water holding capacity is determined by these variables. The chemical properties considered were: (1) topsoil organic C concentration, and (2) soil profile organic $N$ concentration. The annual rainfall erosion rate and the mean maize, wheat and soybean yields were also considered.

2.3. Study area. The Rolling Pampas is a subregion of the vast pampean plain, located between $32^{\circ} \mathrm{S}, 64^{\circ} \mathrm{W}$ and $36^{\circ} \mathrm{S}, 57^{\circ} \mathrm{W}$. The topography is slightly rolling, with slopes of $5 \%$ or less. The annual mean temperature is 15 to $18^{\circ} \mathrm{C}$, with 200 to 220 frost-free days from October to May. The mean annual precipitation ranges between 900 and $1100 \mathrm{~mm}$ and the mean annual potential evapotranspiration is between 1200 and $1300 \mathrm{~mm}$. In general soils are deep and of the Mollisol type. The Vertic Argiudolls are dominant in the vicinity of the Paraná River; Entic Hapludolls are found in the southwest of the region, and Haplustolls on the western side of the Carcaraña River basin. The majority of the soils are Typic Argiudolls.

The Arrecifes and Carcarañá River basins presented 2 advantages for the study: (1) $70 \%$ of the area is covered by agricultural soils where the prevailing production system consists of continuous rotation of grain crops and oilseeds, and (2) rainfall erosion is the main soil quality limiting factor. 
2.4. Assumptions of the simulation. The methodology for simulating future conditions implies a series of assumptions, such as:

(1) The use of synthetic weather data can produce satisfactory results. This assumption has been verified for Pergamino County (Díaz \& Di Giacomo 1994).

(2) The climate change scenario considered is certain to occur. This assumption is likely to be incorrect due to the current limitations in knowledge on this issue (Hulme et al. 1990).

(3) The climate is in equilibrium. EPIC does not modify the parameters during the simulation process.

(4) The management schedule and the rotation system are representative of typical management practices.

(5) The future technological scenario does not differ from the current situation. This assumption results from the lack of information on the agrotechnological pathways for the next 50 years.

\section{RESULTS}

The effects of climate change on soil properties can be assessed by means of 2 variables which define soil quality and consequently its sustainability: water-holding capacity and potential fertility level.

Following this criterium, results are presented in 2 sections according to: (1) changes in physical properties related to water storage, and (2) evolution of soil C and $\mathrm{N}$ concentrations as indicators of changes in chemical properties.

\subsection{Physical properties}

In relative terms, the topsoil bulk density is the physical variable which most significantly changed with respect to the baseline scenario (no climate change). However, in only $9 \%$ of the cases ( 4 out of a total of 45 soils) is its value estimated to increase by 1 to $10 \%$. These soils belong to the following series: Casilda severely eroded phase ( $\mathrm{CaH} 3$ ), Correa severely eroded phase (CrrH3), Villa Eloísa (Ve1Ho) and Villa Eloísa severely eroded phase (Ve2H3).

The water parameters fluctuate within a wide range: from 0.216 to $0.421 \mathrm{~m}^{3}$ of water per $\mathrm{m}^{3}$ of soil for the field capacity, and from 0.153 to $0.340 \mathrm{~m}^{3}$ of water per $\mathrm{m}^{3}$ of soil for the wilting point. In spite of the soils being very diverse and having different properties, no differences are found between the 2 scenarios with regard to the final values for the soil profile.

The loss of topsoil depth is estimated to be similar with or without climate change. Only 9 out of the 45 soils having a depth between 0.97 and $2.69 \mathrm{~m}$ would suffer a $1 \%$ greater decrease by the year 2050 should climate change occur. This small difference would have a certain spatial pattern, since it would affect soils with moderate to severe erosion risk (Arrecifes moderately eroded phase, ArH2; Arrecifes severely eroded phase, $\mathrm{ArH} 3$; Casilda moderately eroded phase, $\mathrm{CaH} 2$; Correa severely eroded phase, CrrH3; Hansen severely eroded phase, $\mathrm{Ha}_{4} \mathrm{H} 3$; and Villa Eloísa severely eroded phase, Ve2H3). Delgado series (De)a shallow Haplustoll -- would be an exception, since its final depth under the climate change scenario was estimated at $2 \mathrm{~cm}$ greater than under the baseline scenario. As suggested by the GISS model, an increase in precipitation is likely to improve the water balance in the areas having the lowest water holding capacity and depth among all the environments under consideration (represented by the lower limit of the ranges).

Comparison of the initial and final soil depth indicates that the mean annual erosion rate would not vary as a result of climate change. This is considered to be a valid comparison since the weather data generated under both conditions (baseline scenario and climate change scenario) were the same, as monthly half-hour rainfall and its $10 \mathrm{yr}$ frequency remained constant.

Loss of soil depth would range between 0 and $17 \mathrm{~cm}$ in a $55 \mathrm{yr}$ period. Assuming a soil bulk density of $1.3 \mathrm{Mg} \mathrm{m}^{-3}$, the average rate would range between 0 and $40 \mathrm{t} \mathrm{ha}^{-1} \mathrm{yr}^{-1}$. The estimate of the average rate corresponding to the 1971 to 1995 period, for which measured climate data were used, is slightly higher (5 to $42 \mathrm{tha}^{-1} \mathrm{yr}^{-1}$ )

\subsection{Chemical properties}

A general reduction in the total organic $N$ content of the soil profile is predicted under climate change conditions. By the middle of the next century this parameter is estimated to range between 4061 and $13644 \mathrm{~g}$ $\mathrm{Mg}^{-1}$ under baseline scenario conditions, and between 3649 and $12354 \mathrm{~g} \mathrm{Mg}^{-1}$ should temperature, precipitation, radiation and $\mathrm{CO}_{2}$ levels increase. The average relative decrease would be $8 \%$. The magnitude of organic $\mathrm{N}$ loss is shown in Table 2.

Organic $\mathrm{C}$ would follow the same decreasing trend as organic $N$, although more markedly (Table 3). EPIC simulates a 0.63 to $1.47 \%$ range of organic C content in the topsoil for the year 2050 under a non-climatechange situation. However, this range would be between 0.5 and $1.36 \%$ under climate change conditions.

The estimated decrease would be 7 to $20 \%$. The greatest decreases correspond to soils of the Carcarañá River basin (Baldissera, Hughes, Maciel and Villa Eloísa series). 
Table 2. Distribution of soil organic $\mathrm{N}$ content in different soils under the baseline and climate change scenarios

\begin{tabular}{|lcc|}
\hline $\begin{array}{l}\text { Final organic } \\
\text { N content } \\
\left(\mathrm{g} \mathrm{Mg}^{-1}\right)\end{array}$ & $\begin{array}{c}\text { No. of cases } \\
\text { (baseline scenario) }\end{array}$ & $\begin{array}{c}\text { No. of cases } \\
\text { (climate change } \\
\text { scenario) }\end{array}$ \\
\hline $2000-3999$ & 0 & 1 \\
$4000-5999$ & 5 & 6 \\
$6000-7999$ & 10 & 14 \\
$8000-9999$ & 20 & 17 \\
$10000-11999$ & 8 & 5 \\
$12000-13999$ & 2 & 2 \\
\hline
\end{tabular}

Table 3. Distribution of soil organic $C$ content in different soils under the baseline and climate change scenarios

\begin{tabular}{|lcc|}
$\begin{array}{l}\text { Final organic } \\
\text { C content }\end{array}$ & $\begin{array}{c}\text { No. of cases } \\
\text { (baseline scenario) }\end{array}$ & $\begin{array}{c}\text { No. of cases } \\
\text { (climate change } \\
\text { scenario) }\end{array}$ \\
\hline $0.50-0.69$ & 4 & 10 \\
$0.70-0.89$ & 12 & 16 \\
$0.90-1.09$ & 10 & 7 \\
$1.10-1.29$ & 12 & 11 \\
$1.30-1.49$ & 7 & 1 \\
\hline
\end{tabular}

\section{DISCUSSION}

\subsection{Physical properties}

Two soil series of the eastern part of the Carcaraña River basin, Correa (CrrH3) and Villa Eloísa (Ve1Ho and $\mathrm{Ve} 2 \mathrm{H} 3$ ), are characterized by the lowest variation in water-holding capacity under climate change conditions. In these cases a decrease in soil profile depth occurs together with an increase in soil bulk density. The topsoil becomes more dense as a result of the addition of fine material from the subsurface layer caused by plowing. Under climate change conditions the accumulated loss in soil depth would be 10,6 and $17 \mathrm{~cm}$ respectively for each soil type, as a consequence of rainfall erosion. However, the fact that water parameters did not vary means that the potential soil storage capacity would not be modified. These results indicate that the variation in the physical properties would be restricted to the topsoil, with only a moderate impact on the soil profile characteristics.

The annual average erosion rate would not differ under the 2 scenarios, even though a $20 \%$ decrease in precipitation during September and a 20 to $60 \%$ increase from January to April are predicted by the GISS model. Robertson et al. (1987) stated that soil loss due to rainfall erosion could either be lower or higher depending on the interactions between the environment and the production system. In the wheat planting area of England a precipitation increase would enhance soil erosion under a climate change scenario (Favis-Mortlock et al. 1991). In both of the cited studies the current situation was considered as the baseline scenario.

A 40 to $60 \%$ decrease in the erosion rate was found when comparing the conditions in both river basins under the climate change scenario with regard to the mean values for the 1971 to 1995 period (18 cases out of 45). The erosion rate would increase only in 5 soil series, namely the Vertic Argiudolls (Portela, Río Tala and Ramallo) and the soils with high clay content (Urquiza and Arroyo Dulce), located in the area having the highest relative precipitation (San Pedro).

The comparison with historical data is only partially appropriate, since while observed weather data were used for 1971 to 1995, the information for years after 1996 was simulated. One additional limitation is related to the fact that erosion is more dependent on the maximum half-hour storm intensity than on total precipitation (Wischmeier \& Smith 1978). At present there is almost no information on potential variations in storm intensity caused by climate change (Parry \& Carter 1988). Consequently, even though EPIC uses the average monthly erosion intensity as a variable, the values under both scenarios were the same.

Further, Favis-Mortlock (1994) found that erosion indices estimated with synthetic precipitation values were lower than the real values, thus identifying a significant limitation of the weather generators included in EPIC.

\subsection{Chemical properties}

EPIC produces daily simulations of $\mathrm{C}$ balance and $\mathrm{N}$ balance by comparing the supply and loss processes in the soil profile. The incorporation of crop residues and their decomposition are 2 of the processes involved.

Under climate change conditions with an increase in $\mathrm{CO}_{2}$, EPIC simulates 5 to $20 \%$ decreases in biomass production with respect to the baseline scenario. Other studies have indicated the possible reduction in grain yield of the main crops of the pampean region (Rodríguez \& Fernández 1993, Rosenzweig \& Parry 1994).

A higher mineralization rate as a consequence of climate change also adds to the potential soil fertility loss. The increase in the organic matter decomposition rate with temperature and soil moisture was demonstrated by Ayanaba \& Jenkinson (1990) and by Orchard \& Cook (1983), respectively.

The consequence of erosion for the reduction of $\mathrm{C}$ and $\mathrm{N}$ final content would not be significant, since no differences were found between the 2 scenarios and 
since it is only a surface process. According to Lal (1995) the annual average $C$ decrease in the ecosystems due to erosion would amount to $0.38 \%$ of the accumulated soil $\mathrm{C}$.

Should both climate change and increase in $\mathrm{CO}_{2}$ occur, soil sustainability under continuous agriculture would be at risk. Under such conditions, by the middle of the next century soil production capacity and soil quality would be lower than under a scenario with no change in climate or as compared to the current conditions. At the end of the past decade Michelena et al. (1989) measured a $47 \%$ decrease in the natural fertility of soils of the Rolling Pampas, which at that point had been subject to 20 yr of continuous agriculture. Therefore, the scenarios used for the analysis of sustainability degradation should always take into account the environment-agroecosystem interactions.

Simulation could be used to compare different technological scenarios (e.g. land use, rotation type and frequency, planting dates) and to analyze quality indicators such as organic $\mathrm{C}$ and $\mathrm{N}$ dynamics, in order to develop a strategy for sustainable soil use.

\section{CONCLUSIONS}

The potential impacts of climate change combined with an increase in $\mathrm{CO}_{2}$ on soil properties can be summarized as follows:

(1) No changes would occur with regard to most physical variables. The exception would be the topsoil bulk density of 4 soils of the Rosario region characterized by moderate to severe rainfall erosion risk, where the subsurface clay carried to the topsoil would cause a 1 to $10 \%$ increase in this parameter with respect to the values without climate change.

(2) There would be no differences in the average erosion rate under the 2 scenarios. This is probably due to the fact that it was not possible to use variable values for maximum precipitation intensity.

(3) A general decrease of 20 to $40 \%$ in the annual erosion rate with respect to the historical average for the 1971 to 1995 period is predicted. This rate would increase by 1 to $20 \%$ in 6 soil series of the Arrecifes River basin due to a relative increase in runoff. The example illustrates one of the problems encountered in the literature when comparing the results obtained with real and generated weather data.

(4) The chemical degradation of the soils would include a 6 to $10 \%$ reduction of organic $N$ and a 7 to $20 \%$ reduction of organic $\mathrm{C}$ in the topsoil with respect to the no-climate-change situation. This difference could be explained by a lower dry matter production and an increase in the mineralization rate due to global warming
(5) The decline in sustainability of the permanent agricultural production system due to the soil quality degradation points out the need to consider alternative land use and management scenarios.

The EPIC model outputs differ according to the combined climate-soil and management-practices conditions at each site, which function additively to the specific initial conditions. It is therefore suggested that additional studies on the issue be conducted in the near future. The main objective of such studies should be to provide orientation for actions in order to ensure soil quality preservation and sustainability of agroecosystems in the event of a change in climate.

\section{LITERATURE CITED}

Ayanaba A, Jenkinson DS (1990) Decomposition of C-14 labelled ryegrass and maize under tropical conditions. Soil Sci Soc Am J 54:112-115

Burgos JJ, Molion LCB (1991) Climate change predictions for South America. Clim Change 18:223-239

Díaz RA (1993a) Aplicación del modelo EPIC para estudiar el efecto de las labranzas sobre la producción de cereales y oleaginosas. Actas de la II Reunión Bianual de la Red Latinoamericana de Labranza Conservacionista (RELACO). Esteción Experimental Araure, Fondo Nacional de Investigaciones Agropecuarias, Araure, Venezuela

Díaz RA (1993b) Development of a system for a field-scale, continuous-time model designed to simulate the effect of tillage equipment on soil roughness, crop residue, hydrology and nutrient cycling. Final Report FAO Agreement CMT 56128. Land and Water Development Division, FAO, Rome

Díaz RA, Di Giacomo RM (1994) On the comparison of measured and EPIC-simulated fertility losses in the Rolling Pampas of Argentina. Transcripts of the XV World Congress of Soil Science, Vol $7 \mathrm{~b}$, Commission VI. Instituto Nacional de Estadistica, Geografia e Informatica, Acapulco, p 229-230

Díaz RA, Di Giacomo RM, Moscatelli G (1994) Efecto del cambio climático sobre la fertilidad, erosión y productividad de los suelos en la Pampa Ondulada Argentina. Actas del Simposio 'Cambio climático y Geología en la Argentina'. Sociedad Argentina de Geología, Buenos Aires

Easterling WE, Rosenberg NJ, McKenney MS, Jones CA, Dyke PT, Williams JR (1992) Preparing the erosion productivity impact calculator (EPIC) model to simulate crop response to climate change and the direct effects of $\mathrm{CO}_{2}$. Agric For Meteorol 59:17-34

Favis-Mortlock DT (1994) The use of synthetic weather for soil erosion modelling. In: McGregor D, Thompson D (eds) Geomorphology and land management in a changing environment. Wiley, Chichester, p 1-27

Favis-Mortlock DT, Evans R, Boardman J, Harris TM (1991) Climate change, winter wheat yield and soil erosion on the English South Downs. Agric Sys 37(4):415-433

Hansen J, Fung I, Lacis A, Lebedeff S, Rind D, Ruedy R, Russell G. Stone P (1988) Global climate changes as forecast by Goddard Institute for Space Studies three-dimensional model. J Geophys Res 93:9341-9364

Hulme M, Wigley TM, Jones PD (1990) Limitations of regional climate scenarios for impact analysis. In: Boer MM, De Groot RS (eds) Landscape-ecological impact of climatic change. IOS Press, Amsterdam, p 111-129 
Lal R (1995) Global soil erosion by water and carbon dynamICs. In: Lal R, Kimble J, Levine E, Stewart BA (eds) Soils and global change. CRC Press, Inc, Boca Raton, p 131-142

Michelena RO, Irurtia CB, Vavruska FA, Mon R, Pittaluga A (1989) Degradación de suelos en el norte de la región pampeana. INTA, Proyecto de Agricultura Conservacionista, Publicación Técnica No. 6, Pergamino

Orchard VA, Cook FJ (1983) Relationship between soil respiration and soil moisture. Soil Biol Biochem 15:447-453

Parry ML, Carter TR (1988) The assessments of effects of climatic variations on agriculture: aims, methods and summary of results. In: Parry ML, Carter TR, Konijn NT (eds) The impact of climatic variations on agriculture, Vol 1 , Assessment in cool temperate and cold regions. Kluwer Academic Publishers, Dordrecht, p 11-96

Robertson T, Benson VW, Williams JR, Kiniry JR, Jones CA (1987) Impacts of climate change on yields and erosion for selected crops in the southern United States. In: Proceedings of the Symposium on Climate Change in the Southern United States: future impacts and present policy issues. Science and Public Policy Program, New Orleans, USA, p 89-134

Rodríguez RO, Fernández NR (1993) Cambio climático en la región pampeana argentina y su probable efecto sobre la producción triguera. Rev Invest Agropecu 24(1):83-99

Rosenzweig C, Parry ML (1994) Potential impact of climate change on world food supply. Nature 367:133-138

Williams JR, Jones CA, Dyke PT (1984) A modeling approach to determining the relationship between erosion and soil productivity. Trans ASAE (Am Soc Agric Eng) 27(1): $129-144$

Wischmeier WH, Smith DD (1978) Predicting rainfall erosion losses, a guide to conservation planning. US Dept of Agriculture Handbook no. 537, Washington, DC 